\title{
SYSTEMATIC ONTOLOGICAL AND GNOSEOLOGICAL APPROACHES TO GEORGE PACHYMERES AND PROCLUS: THE PLATONIC UNCONDITIONED AS THE SOURCE OF TWO DIFFERENT WORLDVIEWS
}

\author{
Christos Terezis - Lydia Petridou
}

DOI: 10.17846/CL.2018.11.1.119-129

\begin{abstract}
TEREZIS, Christos - PETRIDOU, Lydia. Systematic Ontological and Gnoseological Approaches to George Pachymeres and Proclus: the Platonic Unconditioned as the Source of Two Different Worldviews. In this study, the authors focus their attention on the ontological question of the divine essence in Christianity and Neoplatonism, its consequences in the gnoseological field and its historical-philosophical origins from Plato's unconditioned. This is an issue that establishes a common tradition between two clearly different worldviews, which, despite the fact that the first one is monotheistic while the second is polytheistic, they both adopt monism and suggest unutterability of the divine essence. Concerning the structure of the study, the question of the divine essence is firstly approached from the ontological and gnoseological point of view in George Pachymeres, a Christian philosopher and theologian of the Palaeologan Renaissance. It is followed by a discussion on the same question in Proclus. In the last two parts of the study, the authors are discussing the origin of the matter of the agnosia of the divine essence and the transformation of the way in which Metaphysics is approached, following its course from the Platonic moderate anthropocentrism to the Neoplatonic and Christian theological attempt at understanding the divine revelation.
\end{abstract}

Keywords: George Pachymeres, Proclus, Plato, divine essence, unconditioned

\begin{abstract}
Abstrakt: TEREZIS, Christos - PETRIDOU, Lydia. Systematické ontologické a gnozeologické prístupy ku Geórgiovi Pachymérisovi a Proklovi: platónske absolútno ako zdroj dvoch rôznych svetonázorov. Autori tejto štúdie zameriavajú svoju pozornost’ na ontologickú otázku Božej podstaty v krestanstve a novoplatonizme, jej dôsledky v gnozeologickej sfére a jej historicko-filozofický pôvod vyplývajúci z Platónovej idey absolútna. Tento problém vytvára spoločnú tradíciu medzi dvoma zretelne odlišnými pohladmi na svet, ktoré napriek tomu, že prvý je monoteistický, zatial čo druhý je polyteistický, oba prijímajú monizmus a naznačujú nevyslovitelnost' Božej podstaty. Pokial ide o štruktúru štúdie, $\mathrm{k}$ otázke Božej podstaty sa najprv pristupuje z ontologického a gnozeologického hladiska v diela Geórgia Pachyméra, krestanského filozofa a teológa palaiologovskej renesancie. Nasleduje rozbor tej istej otázky v myslení Prokla. V posledných dvoch častiach štúdie autori diskutujú o pôvode problematiky agnózie (nepoznatelnosti) Božej podstaty a o transformácii spôsobu, akým sa pristupuje k metafyzike, od platónskeho mierneho antropocentrizmu k novoplatónskym a krestanským teologickým pokusom o uchopenie Božieho zjavenia.
\end{abstract}

Klúčové slová: Geórgios Pachyméris, Proklos, Platón, Božia podstata, absolútno 


\section{Introduction}

In this study we focus our attention on the ontological question of the divine essence in Christianity and Neoplatonism, its consequences in the gnoseological field and its historical-philosophical origins from Plato's unconditioned ${ }^{1}$. For our systematic remarks, we chose the introductory paragraph of the comments written by the Byzantine philosopher of the Palaeologan Renaissance and, among other things, great commentator of Dionysius the Areopagite' De divinis nominibus (George Pachymerae, Paraphrasis; George Pachymeres 1857, 608 A-C) ${ }^{2}$ George Pachymeres $(1242$ - 1310) and some extracts from the treatises entitled Theologia Platonica (Proclus 19681997) and In Platonis Parmenidem (Proclus 1968-1997; Proclus 2009) of Proclus the Neoplatonist. This is an issue that establishes a common tradition between two clearly different worldviews, which, despite the fact that they both adopt monism, a parameter that makes their representatives to suggest unutterability of the divine essence, they are differentiated in the number of the deities: the metaphysical system in Christianity is completely monotheistic, while in Neoplatonism it is polytheistic.

So, on the one hand, Proclus sets the transcendent true being, which he calls either One or Good, as the fundamental principle and the purpose of any philosophical and theological analysis and does not make any critique of the basic types of Metaphysics, regarding even its epistemological function. Consequently, his point of view concerning the relating names is analogous and this is an issue that requires special attention. The essence of the supreme Principle remains inaccessible and unutterable, while a number of names are attributed to the divine entities, which all together constitute the metaphysical world that comes after the One. The question is as follows: to what extent is an objective attribution of names possible, considering that the metaphysical example is non-negotiable regarding its unutterability?

On the other hand, Pachymeres sets the philosophical and theological terms for a scientific, rational understanding of the sensible world (clearly compatible with the principles of the Christian faith) as a renewed theophany and thinks of God revealing his providence dynamically by making constantly incomparable aesthetic creative appearances. In this way, he brings to the light the past philosophical tradition, remaining however devoted to the Christian principles and giving divine names just to the projections of the divine energies. His permanent rule is that God creates the natural universe without emanating himself by his essence, but only by what is derived from the infinite in numerous combinations of his divine energies.

We have to mention that both thinkers, utilizing the tradition that each of them follows, make a radical theological approach to the ancient Greek Metaphysics and turn it into Henology (Semmelroth 1952, 1-11; Trouillard 1965; Schürmann 1982, 331-334).

1 On this issue, cf. for instance in Respublica, where, after the discussion on the similarity between the good and the sun and, consequently, after the division into the intelligible and the sensible world, Plato, having suggested that each world may be divided into two parts, comes to the following conclusion: «H tò $\mu \dot{\varepsilon} v$

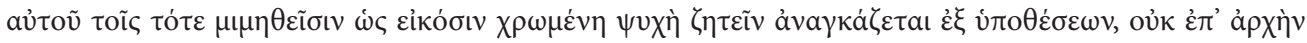

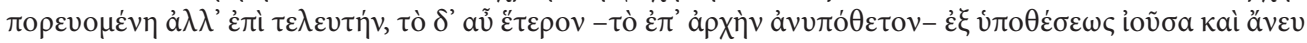

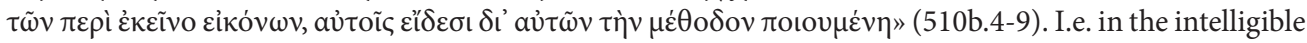
world there is a part in which the soul moves towards an unconditioned and absolute Principle, which is identified to the truth, relying exclusively on the Ideas.

2 This is a text about God's properties and names, which arise from the divine provisions and energies. It is remarkable that it has been investigated by thinkers of the Western Christianity too. One of the most important of them is Albert the Great (Ruello 1963). 


\section{The question of the divine essence in G. Pachymeres: an ontological and gnoseological approach}

In order to emphasize, both in the ontological and the gnoseological field, the distinction between the metaphysical and physical plane, G. Pachymeres points out from the beginning that God's essence may not be known by any created being, not even by the immaterial angels; in other words, the divine essence is strictly unparticipated regarding the communication by both the sensible

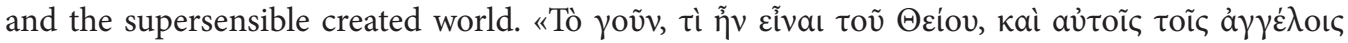

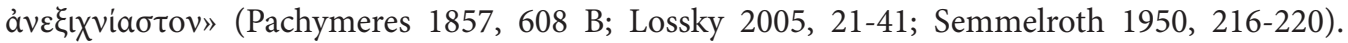
By this remark, the discussion receives universal application features. If we attempted to present the priorities followed by Pachymeres, we would say -and that would be actually mandatory- that ontology is the precondition for gnoseology. If we summed up the entities and the theoretical schemes that describe them in an initial unity and if we described all this, in Hegelian terms, as reason, we would say that there is a clear relationship between them. However, how would these two factors come together? The Christian philosopher explains that this is not just a cognitive inability of the created beings. The most important thing is not the boundaries of the cognitive ability of the human mind but the very nature, the ontological texture of God, which is independent of any relation and as such is absolute, not decodable by even the highest-performance rational

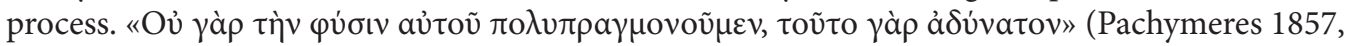
$608 \mathrm{~B}-\mathrm{C})$. I.e. He suggests that there is no created being that could exceed the unutterability of God, in the sense that God transcends anything else gnoseologically (Terezis 1993, 98f) ${ }^{3}$. By this remark,

3 Ch. Terezis says that in Christian thought human being's cognitive ability is not complete and is limited by uncertainty regarding the metaphysical issues. Furthermore, keeping in mind that knowledge, as both method and evidence, is just a tool and does not provide an exclusive way-path to the truth, it is noted that the ability is more or less a possible choice and a dynamic direction and not an "objective" certainty. And ability means personal readiness to access the analogue knowledge. I.e. it is a factor that is not determined by objective necessities; so, it stops the process for autonomy and enforcement of the method as evidence. Possible acceptance of such autonomy would eventually mean that God may be actually known; however, that would cause ontological consequences as regards 'theosis' as man's perfection by nature and not by grace. The ontological parameter would be a fact from the beginning and would result in the fact that man does not need to follow any development. He is just asked to actualize what he is, so, 'theosis', in the sense of a final condition, is out of question. It would have been set as an original fact, it would have gone into oblivion and the only thing that would be expected would be restoration. This would be either a formed or a chosen unnatural condition, which would return to its complete natural condition. There is no such scheme in Christianity, at least since the period of time after Origen. We have to mention too that analogical knowledge does not lead to an absolute ambiguity, since the supreme reality may be considered as a genus from which ontologically similar species derive. So, may meanings could be attributed to the One-Good. Consequently, maybe the term "analogy" is not successful and causes some questions. On this matter P. Ricœur $(1975,332)$ says the following: «Lanalogie désigne virtuellement cet affaiblissement progressif de la précision de la fonction prédicative, à mesure qu'on passe de la prédication primordiale à la prédication dérivée, et de la predication essentielle à la prédication accidentelle (qui est paronymique). Ce qu'on appellera ultérieurement analogie d'attribution est ce lien de dérivation progressivement relâché qu'Aristote délimite, d'une part, par la prédication essentielle, qui seule donne lieu aux forms exactes ou approximatives de proportionnalité (auxquelles, on le verra, Aristote réserve le terme d'analogie), d’autre part, par l'homonymie pure et simple ou équivocit». Relying on P. Ricœur's thoughts, we would say that, in both Pachymeres and Proclus, there is a gradual reduction of the categorical function, since the movement from the supreme Principle to its effects is given. In both the researchers we have, on the one hand, the primary-essential attribute -in the sense of a description of the way in which the energies, not the essence exist- when they speak about the metaphysical world (in Proclus in a hierarchized way) and, on the other, the production-accidental attributes, which are about 
he puts himself quite consistently into theological realism and he is not subordinated to the really attractive idealism. In other words, he does not define the human mental centres and their constructions as the primary criterion for the discussion about the way in which the divine exists.

\section{The question of the divine essence in Proclus: an ontological and gnoseological approach}

This conclusion, with some differences, is also found, to a certain extent, in some cases of the Neoplatonic School, according to which it is suggested that human being is able, after a long dialectical gradual ascent, to reach the knowledge on God, but not completely. For the Neoplatonic philosophers, the inaccessibility of the divine essence is a matter of fact; the divine essence is ontologically considered to be totally unparticipated, completely separated from anything that is produced and non-acceptable of any further reduction. Furthermore, we would say that they probably accept that the human consciousness receives a priori some abilities, i.e. it is ontologically founded. Thus, any conceptual scheme that is formed by the observation of the empirical phenomena is found into the initial construction of human mental centres. However, the question on what concepts are pre-included is still relevant. For instance, are the concepts of a plant, a table and a hair found in the same context? In his comments in Plato's Parmenides, Proclus believes that the first concept pre-exists, while the other two do not. Apart from the above discussion, it is a given that there are no concepts by which human being may reach the divine essence, which shows an explicit regularity, which may not be exceeded by any cognitive attempt no matter what. So, the fact that there is no such version in the Neoplatonic texts means that even the internalized knowledge has specific boundaries, no matter if, mysteriously, it is able to reach supreme ontological paths. Absoluteness escapes the risk of its fall completely. Moreover, all the above will occur, provided that the human consciousness is purified from any influence received by sensible data, or at least by a wrong processing/analysis of them. More specifically, according to Proclus, the degree of theognosy is connected, up to a point, with the degree of self-knowledge, which is actualized through dialectical ascents ${ }^{4}$.

the natural world. Note that in Proclus' system it could be used in the metaphysical world too, since it is structured by hierarchical emanation. However, in Proclus' system the second way of attributing will be different in the metaphysical world compared to the natural world. All the above, which compose ontology and gnoseology, absolutely justify ambiguity as a descriptive, in an analogous way, of the two worlds. We should mention, however, that Pachymeres' and Proclus' ontological universes are quite different from that of Aristotle's, since the first two accept monism and realism.

4 In the third chapter of the first book of Theologia Platonica (Proclus 1968 - 1997, 12.1-17.8) - which establishes quite clearly the epistemological principles-, Proclus describes the reducing course that a human being follows during the process of theologizing. In this chapter, he also attempts to provide a definition of theology as a strict science. The starting points are quite indicative of what will follow. In his first introductory remark, Proclus, relying on an extract of the Platonic Republica (379.a5-6), says:

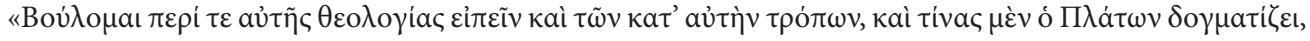

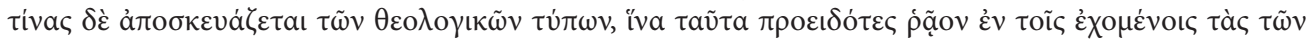

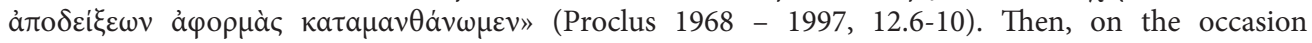

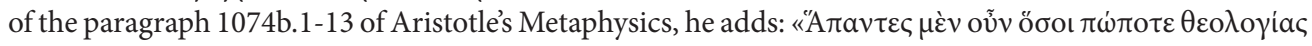

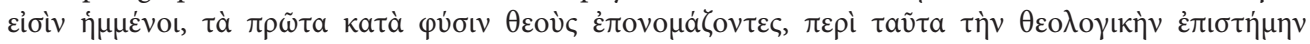

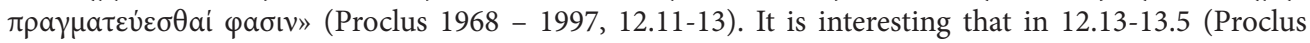
1968 - 1997) In short, Proclus presents some views on the structure of the ontological system and its hierarchies, drawing on the legacy of ancient Greek philosophy. He then brings to the fore the Platonic texts. We have to mention that according to the Neoplatonist philosopher, the divinely inspired teaching 
of the founder of the Academy puts all the material beings to an inferior ontological position than the Principle's. The reasoning also introduces an axiological dualism between the body and the soul; the main argument for that is the divisibility of the matter. This feature prevents any material thing from the process of self-production and eternal self-standing in the state of existing. Souls' essence is proved to be superior to the bodies', since the soul is able to actualize all the above and possesses the everlasting life that the matter does not have. However, the soul is subject to a superior reality and depends on the hypostasis of the intellect, which is considered to be the cause of the bodies and the souls. From this point of view, we could say that a triadic anthropological model is introduced, according to which the order, both hierarchically and axiologically, from the inferior to the superior, is the following: Matter, Soul and Intellect. These are conditions that participate in more general formations of the ontological system. Note that here everything is for just some of the entities that the Neoplatonist philosopher has included in his system. However, he finds in the Platonic another principle, completely independent of the Intellect, much more immaterial and mystical, from which everything that exists is derived, including the first and the last being. This is an approach of Plato by Proclus according to his theoretical criteria, which at least are much more detailed and according to which not all the beings participate in the new approach of the Soul. Accordingly, they do not participate on the Intellect or on the Life or on the Essence, i.e. on the leading, after the supreme Principle, ontological categories. They participate, however, in an indirect way, on the Principle of everything, which has provided hypostasis in any way and on everything within the metaphysical and the natural world. The Neoplatonist scholar thinks that the Platonic philosophy discovered in this primary Cause the three causes that were presented, which, as undivided units, are beyond the bodies: the Soul, the Intellect and the Union, which is beyond any ontological condition and it is the most important property that is found in any other hypostatic scheme that is being formed, in a hierarchical graduation. We are speaking about what is given by the One-Good. From these causes, corresponding multitudes are produced, the psychic, the intellectual and the united. Each of them as a unit precedes its relative multitude and returns through a series of connections everything to the one Henad -which is the name of the first Principle-, which does not accept any participation directly. In fact, everything reverses to the specialized henad that corresponds to each class. The power that orders this to happen is the One, the first Henad, which sets the terms for architectural structures. More specifically, the leading henad joins together the bodies and the souls, the souls and the intellectual species and the intellectual species and the henads of the beings. However, it should be mentioned once again that this description is particularly general, since the classes of the beings in Proclus exceed the abovementioned, in an actually large extend. Plotinus particularly limited metaphysical multiplying was no longer accepted. In the late Neoplatonism there are so many deities that man obviously is not able to describe them. However, it is defined -as in all of the other issues- that the supreme Henad is the leading ontological condition according to which everything else will be explained. It is also the truth of the other gods, since its emanation through the henads of the beings provides, in man's gnoseological abilities, the "processions" and the properties of the beings, as well as their connection to the units -as primary sources- and the graduated ontic planes -as multitudes-, which primarily and absolutely depend on the united beings. So, in the context of these hierarchies, the theory on the Intellect is considered to be inferior to the theory on the gods-henads, according to the application of the adopted ontological state. The most important thing that comes up from Proclus' thought is that the Intellect -as well as the Essence and the Life- is connected to the henads of the true beings and through them to the mystical Union of all the divine henads. On the other hand, on an anthropological level, the intellect, as part of the metaphysical Intellect, is the power with which man comes in contact with the divine and, furthermore, participates on its provisions in an authentic way. Any approach of the divine through senses or even through perception and thinking with logical reasoning is totally out of the question, since they are cognitive paths about what is related to the whole of the true beings. Therefore, the divines, which are only hypothetically approached, are excluded from this possibility. From the above reasoning it also follows that the divine becomes, up to a point, known through soul too, which is the point of similarity between human beings and gods. More specifically, the soul entering itself will see all the other beings and some aspects of the divine existence (cf. Alcibiades I, 133b). According to 


\section{The origin of the matter of agnosia of the divine essence}

The matter that we are discussing has actually one more dimension that should not escape our attention and it comes from Plato's middle period. It is associated especially with the Platonic theory on anamnesis, which was basically about the divine nature of the soul and partially about human being itself. The matter, both ontologically and anthropologically, took advanced dimensions, since it seemed that God was not the only one in the metaphysical world. He was not alone. So, despite the fact that Proclus could easily suggest the a priori establishment of the human consciousness, he is not dogmatic in defending this theory. He is not attracted, although it is quite charming, to a coexistence of the divine-human, because of his non-negotiable position on the metaphysics of transcendence. He insists on a conscious reading of the self by the man himself, where he may find established the a priori details of what has been gnoseologically acquired, but not completely comprehended. In the way in which this immanence is set, one may see the regularity regarding the duties that have been set, which he believes that human being is asked to actualize. Since his birth, it is believed that man is in a discussion with the divine and it is meant for him to develop this very property in his nature. However, there are plenty of cases in which the Neoplatonic philosopher says that man is "challenged" by the sensible things so as to reach the intelligible things; so, he provides extra value to the natural world, which he actually thinks constitutes a reality derived by the divine active causality. He avoids, however, at least directly, dealing with the decisively intermediate anamnesis, i.e. he avoids giving it a key role that would turn it into a key factor in the adjustment of ontology. We are of the opinion that the fact that he does not refer to any so strong determining processes should not escape our attention, mostly for ontological reasons. Anamnesis means that human being coexists with the divine; but Proclus does not support such an idea, since his theology has an original content that does not share its integrity with other realities. The metaphysical world is totally self-founded; this is an absolute condition that has no need to accept some other co-existences. Why would he turn anthropology into a partner of theology? He is just interested in giving emphasis to the theological feeding of the human existence, to show the benevolent presence of the One and of the rest of the deities to every personal individual ${ }^{5}$. What he says is that

the text, this is an inner motion of the soul, which may be defined as a gradual self-knowledge. This process begins from the view of the soul itself, which deepens and finds intellect and the classes of the being and really deep inside it finds also gods and the henads of the beings. Everything is based on the fact that everything exists within the soul and that any knowledge can be understood through an awakening of the powers that are found inside human being and through the images of everything, which are real and not creatures of the imagination. The ascent of the physic powers to the divine, which Proclus calls "perfection of the energy" is completed with the ascent, up to a certain degree, to the very Principle of the beings. Regarding the Neoplatonic gnoseological ascent to the metaphysical world, through the deepening of the soul in itself, i.e., through self-referencing, L. Couloubaritsis $(1982,323 f)$ claims that this is not an option in Christianity, since this is an ability possessed only by God. He says, however, that the new idea in the Christian tradition, to which Pachymeres belongs, is that it makes a composition between the impossible and the possible knowledge about God, from which various types of theology emerge: the affirmative, the apophatic, the symbolic, the mystical. These are ways to refer to God, which not only show the degrees of the existential maturity but also the methodological "maneuvers", which come from the deep awareness of the cognitive abilities. Among these methods one may find some internal differences. For instance, apophatic theology is mainly gnoseological, while mystical theology has a wider existential content. The first one can find things, while the second is ecstatic. However, these differences do not demonstrate an absolute unilateralism. It is simply defined which of them is the leading one to start with or to further process.

5 Cf. for instance In Platonis Parmenidem (Proclus 2007) 617.1-618.13. This is the introduction to the treatise in which Proclus explains how a man with specific questions, speaks both theoretically and mystically 
the divine puts into the human consciousness the theoretical reasons and, thus, he does not allow, in any way, pantheism to appear. Human self has divine characteristics given from above, but it is not a god.

\section{The transformation of the way in which Metaphysics is approached: from the Platonic moderate anthropocentrism to the Neoplatonic and Christian theological attempt at understanding the Divine Revelation}

On the other hand, in both worldviews, all the apodictic processes are, to a large extent, the result of the individual critical reflection, which in this way appears to be a major epistemological requirement. This is a reflection that is exclusively associated with the thinking subject regarding its potentials and not with the referent (the transcendent), which, although it is not approachable, is not subject to any doubt regarding its real and absolute existence. Here, one may find an unaccomplished dialectics, regardless of whether its projections are expanded. Its completeness will be achieved when teleological planning will be totally accomplished. Moreover, the necessity of the reflection is mostly based on the fact that it is believed that any stimuli caused by the sensible things and any cognitive effects resulting from them are not able to provide established guarantees. Becoming is continuous and that is why the data are changing and in some cases quite fast and completely. Platonic skepticism is obvious here, but it does not result in a pessimistic and limiting agnosticism of the scientific developments (Terezis 1994, 62-73) ${ }^{6}$. For this reason we may see, for instance, Plato's dialogue entitled Timaues, where doubt

about gods. Together these two ways to approach God exclude any kind of univocity or exclusiveness.

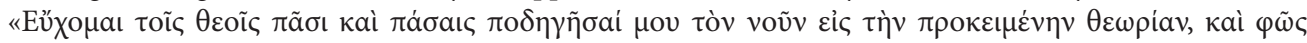

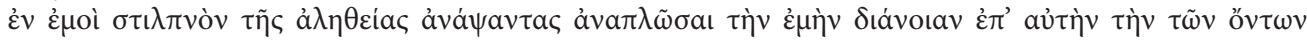

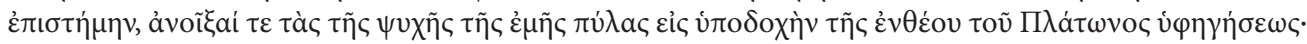

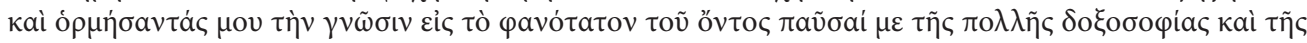

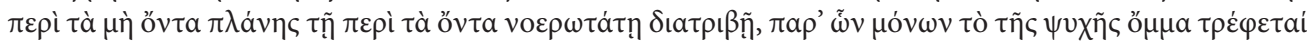

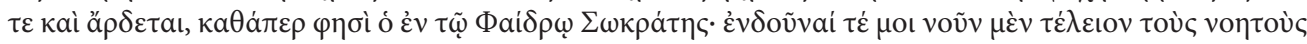

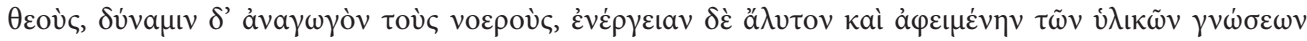

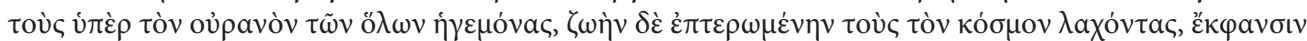

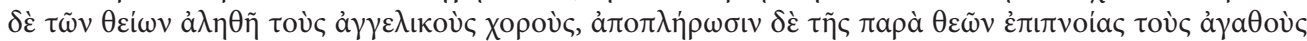

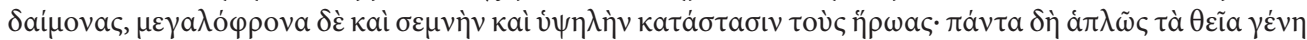

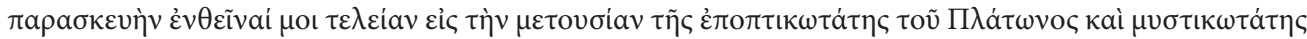

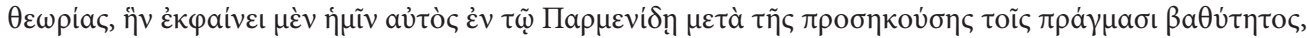

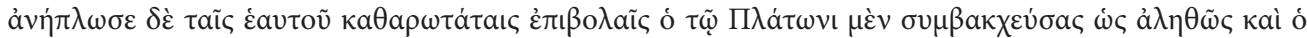

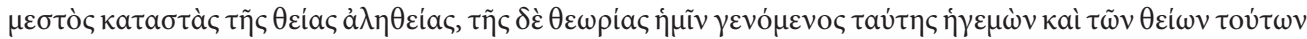

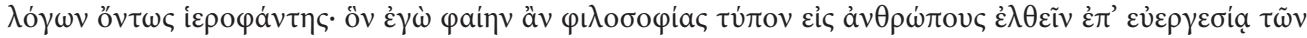

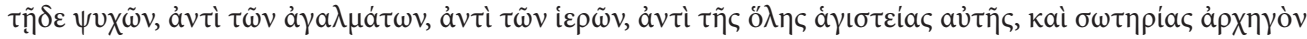

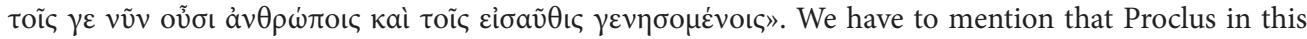
extract uses expressions from the Platonic dialogues Respublica, Phaedrus and Sophista (H. D. Saffrey 1990, 159-172).

6 More specifically, Terezis says that the Neoplatonic philosopher, in one of his first texts found in Theologia Platonica, introduces a special agnosticism, showing in a quite obvious way his disbelief of man's cognitive abilities to capture the deepest essence of the divine cause-principle of the beings. In order, however, for the philosopher from Lycia to preserve the theological foundation of his system, any skeptical questioning of the metaphysical structure is excluded. It is a kind of skepticism for the self as the source of knowledge. Establishing a peculiar Platonism, he introduces a hierarchized axiological rank of cognitive powers and cognitive activities of the human beings, which is expressed by limiting the Aristotelian sensationalism and by putting it in the last cognitive stage. In this context, the supreme cognitive powers 
does not remove the divine action regarding its objectivity. Nothing however is for sure ${ }^{7}$. So, it is necessary to seek the answers to another field, which would be able to provide the foundations and to define the norms. In this field, the "Tì ñरv عĩval" will actually work in an absolute degree. That field is Metaphysics, which, as a general theoretical field, and from the epistemological point of view, is considered to be the source of the ways in which man may think objectively, provided that he is able to reach what it defines exactly.

Obviously the risk here is high, since there is no sensible perception that would ensure what is sensible or measurable. However, the ontological point of Metaphysics and the projections that form Cosmology should not be excluded. In theocentric systems, such as Neoplatonism and Christianity, Metaphysics may be actually described as divine purity and Revelation, while Cosmology as theophany. Moreover, these two worldviews are not developed according to ontological neutrality but according to a personal (and volitional) divine presence. The critical reason is not mans' exclusive self-reference. Obviously, it is something actualized by himself, but in the sense of self-control, regarding whether he has done everything according to the terms set by the divine Revelation. So, here the rules set by traditional philosophy are out of the question, because traditional philosophy has an anthropocentric orientation (Piguet 1991, 61f). Thus, in reverse to the ontological path,

are able to approach quite objectively what exists or what happens in the metaphysical word. We have to mention, however, that in his comments in Timaeus he gives some extra value to sense experience and he investigates whether and how much it could make scientific self-adjustments. This differentiation does not mean a contradiction too. In his treatise Theologia Platonica, he takes the responsibility to establish, in strict scientific terms, a rational and coherent Metaphysics, actually in its highest sense as Henology. On the other hand, his comments in Timaeus are mainly about the sensible world. Since, however, the philosopher is a consistent researcher of holistic type, it is necessary for us to approach his methods as belonging to an epistemological unity that is internally differentiated and explains itself as a system of Knowledge. For a systematic approach of Proclus' epistemological views, cf. also Siorvanes (1996).

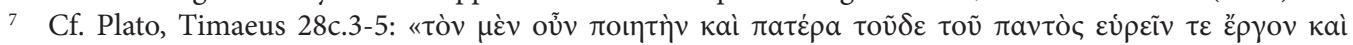

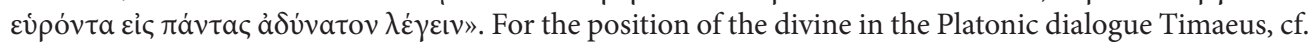
Festugière (1990, 92-152).

8 Piguet says: «De façon profane, le philosophe distingue aussi la connaissance par revelation des autres modes -strictement humains- de connaître. Pour clarifier notre dialogue, j’aimerais appeler "théocentrique" toute connaissance qui résulte d'une revelation, celleci révéland quelque chose qui ne vient pas de l'homme et sur qui l'homme n'a pas de pouvoir. Et j’aimerais appeler "anthropocentrique" toute connaissance qui procède des pouvoirs humains et d'eux seuls. On voit alors aussitôt que ce qu'aujourd'hui on appellee "connaissance" est pratiquement toujours (en science, en philosophie) de type anthropocentrique. Dès le XVI ${ }^{e}$ siècle, en effet, l'accen a été mis sur les pouvoirs de l'homme, pouvoirs que la connaissance lance à l'aussaut de l'Etre; et le siècle des Lumières n'a fait qu' accentuer cette tendance, pour ne rien dire du positivism plus recent. C'est pourquoi le philosophe a quelque peine à retrouver l'état ancient (antique surtout) d'une connaissance par revelation. Toutefois l'histoire de la philosophie en donne de bons exemples. Ainsi l'affirmation de l'Etre chez Parménide procède d'abord de l'Être (qui est affirmé) et non pas de son affirmation, qui précéderait l'Etre. Il y a donc chez Parménide comme une "revelation" de l'Etre antérieure à l'affirmation de l'Etre. Chez Platon, i lest vrai, l'Être qui se révèle se conjugue avec la revelation (dialectique, donc humaine) de l'Etre. Mais chez Plotin on retrouverait une "presence", antérieure à tout discours et à toute pensée, de l'Un, presence qui se révèle avant qu’on ait humainement à la reveler. Plus tard, il faut bien le dire, la philosophie a été contaminée par le concept théologique de revelation -qui cache autre chose que ce que les philosophes athées aimeraient y mettre. C’est pourquoi, du reste, toute philosophie "théophanique" a passé soit pour de la théologie deguisée, soit pour de la pseudophilosophie de type gnostique ou mystique. Nous devons donc non pas seulement oppose la connaissance par revelation (théocentrique) à toutes les forms profanes de connaissance anthropocentrique (don't le modèle est la science, grecque déjà et surtout modern), mais il faut encore distinguer dans la connaissance théocentrique (par revelation) celle qui est proprement chrétienne et celles qui ne le sont pas nécessairement 
the knowledge of metaphysical world, and its inclusion into categorical schemes are connected to the qualitative -which would actually appear in the precise usage of cognitive methods, such as the abstractive and the leading unmediated henoratic- reading and utilization of the divine provisions by human consciousness. Proclus' aforementioned text is quite typical for showing this tendency. Immediate communication becomes, through regulatory encouragements, an obligation for discovering the authentic. The divine "opening" is a challenge for human being and an introduction into its area is nothing else but the human transformation, which -we repeat- is not autonomous but critical; it works like a restructuring of the cognitive methods-choices.

For Pachymeres, the matter is much clearer regarding apophatism, so the gnoseological definitions -since they are completely consistent with theological realism- for the ontological facts are much wider. In his opinion, the gnoseological goal may be the qualitative transformation of the existence and the gradual or even sudden ascent to the supernatural plane -i.e. the avoidance of remaining just in mind-, however, it is impossible for a human being to know and understand God's essence and, in no way, he could give affirmative names to it. This is a gnoseological conclusion that has both causes and effects (Farantos 1980, 14) . Indirectly but clearly it is obvious that man will never become God as regards its ontological nature. So, the only thing that he can get is its theosis in the sense of ontological completeness, of receiving a new property that is defined by God. So, negation is a gnoseological attitude, totally non-negotiable.

\section{Epilogue}

According to what we have investigated in this study, we could say that Neoplatonism and Christianity, as two worldviews, have a lot in common while their differences are, in some cases, barely noticeable; so, it is reasonable to suggest that they have formed a common tradition. Actually, we could suggest that they both have, as their source, Plato's theory on the unconditioned, while we could also investigate the possibility that they have taken external elements from scepticism. It should also be noted that their terminology has many similarities or they even use the exact same terms and that is a proof that they utilize expressive material that dominated during that historical and cultural period. So, it is very likely that the representatives of the two currents of thought were in close contact or even communication with each other $(\text { Gersh 1978) })^{10}$. And it should not escape our attention

(Parménide ou Plotin, pour prende ces examples)». The above text is particularly clear regarding its conceptual definition and provides meaningful explanations to our study. It provides the researcher with the tools to see when Proclus and Pachymeres -as well as other thinkers- are philosophers and when theologians. It also defines how the divine revelation directs the theological concern, which would rely on the fact that God is exclusively approached in an anthropocentric way. In this approach, Revelation provides power to human being so as to be able to ascent and to make descriptions.

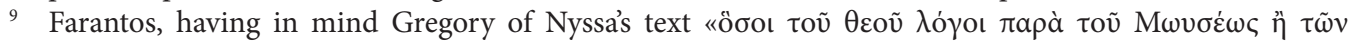

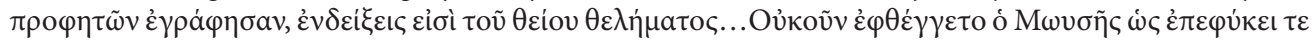

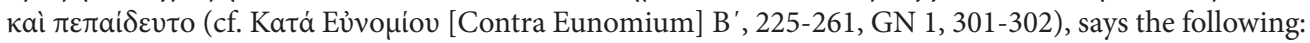
«No language is similar or identical to God's word, so no language is able to have an irreplaceable role in the work of theology. Human word is always an incomplete translation and presentation of the divine word. Consequently, those theologians that use the language of the Fathers of the fifth century, just

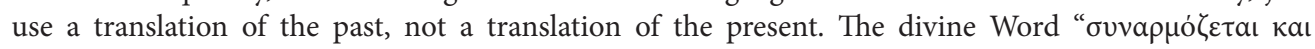

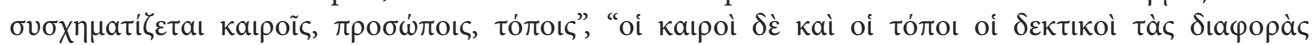

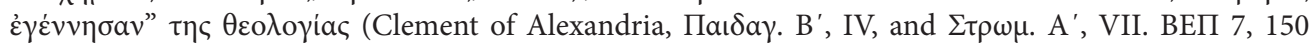
and 249). We must not miss the essence and the spirit for the sake of the letter, by accepting just one specific language for theology, since language is always relative» (1980, 14; trans. Terezis-Petridou).

10 The main advantage of Gersh' study is the precise definition of the categories of thought that have been 
that during the third century A.D. the Schools, in which the future philosophers and theologians of different worldviews were studying, were quite numerous in the late Hellenistic world and had formed a humanistic atmosphere that clearly resulted in existential ecumenism. Although state conditions were not liberal, thinkers, developing their spirituality, understood the universal means and the boundaries in the dialectic relation between human being and God.

We should mention, however, that the answer to the question on theology is niether a complete absence of cognitive accomplishments, nor a pessimistic agnosticism, which would stop any cognitive or existential activity. So, in both Neoplatonism and Christianity together with apophatism, we may also find affirmative names, which show the way in which man understands the divine "processions", in an indirect way through the content of their products. The differentiation of gnoseology into apophatic and affirmative shows, on the one hand, the clear boundaries between the metaphysical and the natural world and, on the other hand, that the second world is the productive extension of the first one. Superlative theology, as the highest point, both ontologically and gnoseologically, has a place in both worldviews, despite the fact that one of them is completely monotheistic while the second one is polytheistic. This kind of theology generalizes quite crucially the view that the supreme Principle is in a self-founding condition, self-determined, self-formed and selfactivated and that is beyond any relation or intellectual approach, even an apophatic one.

\section{REFERENCES}

Couloubaritsis, Lampros, 1982. Le sens de la notion "demonstration" chez le pseudo- Denys. In Byzantinische Zeitschrift 75, 317-335.

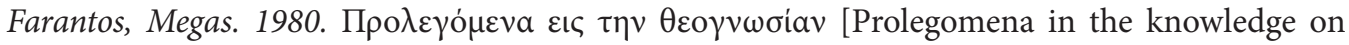

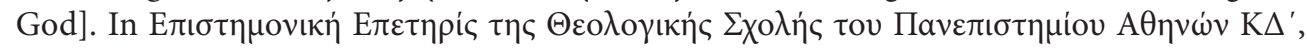

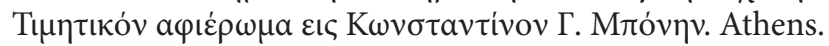

Festugière, André Jean. 1990. La Révélation d’Hermès Trismégiste, 2. Paris.

Gersh, Stephen. 1978. From Iamblichus to Eriugena: An Investigation of the Prehistory and Evolution of the Pseudo-Dionysian Tradition. Leiden.

Lossky, Vladimir. 2005. Essai sur la théologie mystique de l'Église d'Orient, Paris.

Pachymeres George. 1857. Paraphrasis in De divinis nominibus. In Migne, Jacques Paul (ed) Patrologia Greace, 3. Paris.

Piguet, Jean Claude. 1991. Le renversement sémantique. Dialogue d'un théologien et d'un philosophe, Genève Lausanne Neuchâtel.

Proclus. 1968-1997. Theologia Platonica. In Saffrey, Henry Dominique and Westerink, Leendert Gerrit (eds.). Proclus. Théologie Platonicienne, I-IV. Paris.

Proclus. 2007. In Platonis Parmenidem. In Luna, Concetta and Segonds, Alain Philippe (eds). Proclus. Commentaire sur le Parménide de Platon, 1. Paris.

Proclus. 2009. In Platonis Parmenidem. In Steel, Carlos. Procli In platonic Parmenidem Commentaria. Oxford.

Ricœur, Paul. 1975. La métaphore vive. Paris.

Ruello, Francis. 1963. Le "Noms divins" et leurs "raisons" selon saint Albert le Grand commentateur $\mathrm{du}$ "De divinis nominibus", Paris.

Saffrey, Henry Dominique. 1990. Recherches sur le Néoplatonisme après Plotin. Paris.

used and the interpretation of the worldviews that fed them. According to our opinion, this researcher approaches the concept of causality in a quite remarkable way, since he sees it throughout its historical development, through its transformations, which define the meanings that get other similar concepts too or bring to the light new ones. 
Schürmann, Reiner. 1982. L'hénologie comme dépassement de la métaphysique. In Études philosophiques 3, 331-350.

Semmelroth, Otto. 1950. Gottes überwesentliche Einheit. Zur Getteslehre des Ps. Dionysius Areopagita. In Scholastik 25. 216-220.

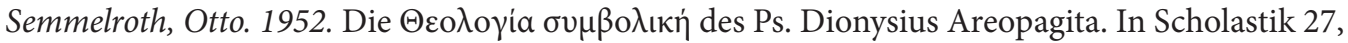
$1-11$.

Siorvanes, Lucas. 1996. Proclus, Neo-Platonic Philosophy and Science. Edinburgh.

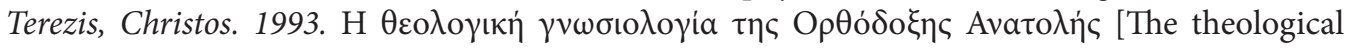
gnoseology of the Orthodox East]. Athens 1993.

Terezis, Christos. 1994. The metaphysical foundation of Gnosiology in neoplatonic Proclus. In Philosophical Inquiry 16, 62-73.

Trouillard, Jean. 1965. Proclos, Eléments de Théologie. Paris.

Zozulak, Ján. 2016. Historické pozadie vzniku byzantskej filozofie [Historical background of the origin of Byzantine philosophy]. In Konštantínove listy [Constantine's Letters] 9/1, 110-118.

\begin{abstract}
SUMMARY: SYSTEMATIC ONTOLOGICAL AND GNOSEOLOGICAL APPROACHES TO GEORGE PACHYMERES AND PROCLUS: THE PLATONIC UNCONDITIONED AS THE SOURCE OF TWO DIFFERENT WORLDVIEWS. The matter of the ontological question on the divine essence and its consequences in the gnoseological field is quite crucial for both Christianity and Neoplatonism, which, despite the fact that they are two worldviews that differ in the number of deities that they accept, both adopt monism. It is a theory the origins of which are found in Plato and his theory on the unconditioned. Taking as examples for the two worldviews George Pachymeres and Proclus, the modern researcher who approaches their work understands first of all that they both suggest that the divine essence may not be described by human beings. More specifically, Pachymeres says that God's essence may not be known even by the angels. Proclus suggests that any knowledge of the divine reality has specific boundaries and is associated with self-knowledge. Finally, it is very interesting for a researcher to follow the course of the transformation of the way in which Metaphysics is approached, since there is a development from the Platonic moderate anthropocentrism to the Neoplatonic and Christian theological attempt at understanding the divine revelation. And that is something that shows the common tradition that has been formed.
\end{abstract}

Prof. Christos Terezis

University of Patras

Department of Philosophy

26500, Rion-Patras

Greece

terezis@upatras.gr

Dr. Lydia Petridou

University of Patras

Department of Philosophy

26500, Rion-Patras

Greece

petridoulydia@yahoo.gr 